\title{
Dynamics of Organic Biofertilizers on Oryza sativa ADT43
}

\author{
Ramya Anandan ${ }^{1,2}$, Lakshmi Priya ${ }^{2}$ and P.Rajendran ${ }^{2}$ \\ ${ }^{1}$ Research and Development Centre, Bharathiar University, Coimbatore, India \\ ${ }^{2}$ Dr. MGR Janaki College of Arts and Science for Women, Department of Microbiology, \\ Chennai, Tamilnadu, India \\ ${ }^{3}$ Department of Microbiology, Shi Ramachandra medical College \& Research Institute, \\ Sri Ramachandra University, Porur, Tamilnadu, India
}

*Corresponding author

\begin{tabular}{|c|c|}
\hline & A B S T R A C T \\
\hline Keywords & \multirow{4}{*}{$\begin{array}{l}\text { Five organic biofertilizers, Panchagavya, Sanjibani, Amritpani, } \\
\text { Jeevamrutha, and Kunapajola were assessed for their potentials to promote } \\
\text { plant growth with Oryza sativa ADT43. Panchagavya was found to have } \\
\text { higher NPK and several other physio-chemical properties compared to } \\
\text { others. Several microbial population also was found higher in Panchagavya } \\
\text { that is most likely to have contributed to paddy plant growth as seen in this } \\
\text { study. Organic biofertilizers holds great promise to increase plant growth, } \\
\text { and yield in an ecofriendly manner. }\end{array}$} \\
\hline $\begin{array}{l}\text { Biofertilizers, } \\
\text { Panchagavya, } \\
\text { Sanjibani, } \\
\text { Amritpani, } \\
\text { Jeevamrutha, } \\
\text { and Kunapajola. }\end{array}$ & \\
\hline Article Info & \\
\hline $\begin{array}{l}\text { Accepted: } \\
\text { 25March } 2016 \\
\text { Available Online: } \\
10 \text { April } 2016\end{array}$ & \\
\hline
\end{tabular}

\section{Introduction}

Impact of farm chemicals in the form of chemical fertilizers, pesticides, insecticides and herbicides necessitates investigating into alternate farm supplementation techniques. Unfortunately, the impact of these farm chemicals have impacted the soil fertility in a serious manner.

The immediate need of the hour is to initiate appropriate remediation measures along with soil enrichment strategies with suitable organic renewable soil nutrients.
Organic farming is one of the best alternative to chemical farming and safe guard the soil from further dilapidation (Ali et al., 2011).

Organic farming involves the judicious combination of green manures, animal manures, biofertilizers, bio/botanical pesticides, and crop rotations, crop residues. There are several kinds of cow based organic manure such as Panchagavya, Sanjibani, kunapajala, amrit pani, etc. Panchagavya (Sanskrit; means a 
combination of five cow products) if formulated properly, is suggested to have miraculous effect on the soil and plants (Geetha and Devaraj, 2013; Rajesh and Jayakumar 2013; Choudhary et al., 2014). Panchagavya is recommended to be used in different forms viz., foliar spray, soil application along with irrigation water, seed or seedling treatment etc., (Natarajan, 2002) with documented benefits on plat growth and increased produce (Swaminathan et al., 2007).

Sanjibani is an organic biofertilizer composed of cow dung and cow urine.

Swaminathan et al., (2007) indicated that Sanjibani improves soil fertility and enhance crop productivity in addition works as a pest-repellent.

Several organic biofertilizers such as Beejamrutha (composition; cow dung, cow urine, water and lime), and Jeevamrutha (composition; cow dung, cow urine, jaggary, pulse flour and water) are shown to be effective in improving the crop yield by enriching the soil nutrition (Srinivasa et al., 2011). In this study, five different organic biofertilizers, Panchagavya, Sanjibani, Amritpani, Jeevamrutha, and Kunapajola were investigated for their possible beneficial effect on crop plant. Oryza sativa, paddy was exposed to these five bioferilizers and its growth response discussed.

\section{Methodology}

\section{Test Crop Plant}

Fresh seeds of Oryza sativa ADT43 (paddy) were procured from Tamilnadu Rice Research Institute (TNRRI), Aduthurai, Tamilnadu and used in this study.

\section{Preparation of Panchagavya}

Panchagavya solution was prepared adopting the methodology described previously with minor modification (Natarajan, 2007). Briefly, fresh cow dung $(7 \mathrm{Kg})$, cow ghee $(1 \mathrm{Kg})$, fresh cow urine (10 liter), cow milk (3 liter), cow milk curd (2 liter), jaggery ( $3 \mathrm{Kg}$ ) and ripened banana (2 $\mathrm{Kg}$ ) were mixed in an open plastic container. On the first day, $7 \mathrm{Kg}$ cow dung was mixed with $1 \mathrm{Kg}$ cow ghee and kept for 72 hours followed by addition of 10 liter cow urine and 10 liter water. The mixture was stirred twice in a day and allowed to ferment for 15 days. On the 18th day, $3 \mathrm{Kg}$ cow milk, $2 \mathrm{Kg}$ cow curd, $3 \mathrm{Kg}$ jaggery and $2 \mathrm{Kg}$ banana were added in the mixture and allowed to ferment for further seven days while stirring twice a day. The Panchagavya was ready for use after a period of 25 days. When stirred twice daily, the Panchagavya solution can be kept for six months without any deterioration in its quality. Whenever the solution becomes thick due to evaporation of water over a long period, suitable quantity of water was added to keep it in a liquid state.

\section{Preparation of Sanjibani}

Sanjibani stock solution was prepared by mixing cow dung $(1 \mathrm{~kg})$, cow urine (1 litre) and water (2 litre) and stored in a plastic container. The mouth of the container was covered with a thin cloth and kept in the shade. This was left to ferment, during this period it was stirred twice a day to release gas and oxygenate the solution. After 9 days it was ready for use.

\section{Preparation of Amritpani}

This was prepared by mixing cow dung $10 \mathrm{Kg}$ with desi ghee $250 \mathrm{gms}$ and honey $500 \mathrm{gms}$. For field application, this material was mixed with 200 liter of water and spread in the field after sowing the crop. 


\section{Preparation of Jeevamrutha}

Jeevamrutha is prepared by mixing $10 \mathrm{~kg}$ of cow dung with 10 litres cow urine, add $2 \mathrm{~kg}$ jaggery, $2 \mathrm{~kg}$ pulse flour, handful of garden soil and the volume made upto 200 litres with tap water in an iron barrel. Barrel was kept in shade covered with wet gunny bag and was stirred thrice a day till use.

\section{Preparation of Kunapajala}

Kunapajala was prepared by following the procedures outlined by Sarkar et al., (2014). It contained Bombay duck fish $10 \mathrm{Kg}$, grind sesame oil cake $4 \mathrm{~kg}$, rice husk $4 \mathrm{~kg}$, molasses $4 \mathrm{~kg}$ and fresh cow urine $30 \mathrm{~L}$. Bombay duck (Harpadon nehereus) was selected as it is cheap, devoid of scales and easy to decompose. These ingredients were taken in an 80L plastic pot, mixed well and allowed to ferment aerobically in shade for 60 days, the preparation was sieved well with the help of a fine cloth and stored for use

\section{Physio-chemical Characteristics of the Biofertilizers}

The physio-chemical characteristics of the five biofertilizers chosen in this study was analyzed using standard methodologies (Cappuccino, 2014). The parameters tested includes, $\mathrm{pH}$, conductivity (EC), Total $\mathrm{N}, \mathrm{P}$, $\mathrm{K}, \mathrm{Ca}, \mathrm{Mg}, \mathrm{Fe}, \mathrm{Zn}$, organic carbon, Indole acetic acid (IAA) and gibberellic acid (GA). All five biofertilizers were also tested for specific group microbes that includes, fungi, actinomycetes, bacteria, phosphate solubilizers and free living nitrogen fixers using standard microbiological enumeration techniques (Cappuccino, 2014).

\section{In situ Plant Growth Analysis with Biofertilizers}

Oryza sativa ADT43, one of the most popular paddy plant was selected and planted in pots ( $n=5 /$ pot/biofertilizer). Five organic biofertilizers chosen in this study were applied to crop planted pot maintaining w/w homogeneity among them. Several plant growth parameters including root length, shoot length, root and shoot dry \& wet weight were recorded. Student's t-test was used to test the statistical significance of the data with alpha set at 0.05 .

\section{Results and Discussion}

Five indigenously prepared organic bioferilizers were subjected to an array of analytical tests for their physio-chemical characteristics and results presented in the table 1. Except Kunapanjola (pH 9.1) all other biofertilizers were in near neutral $\mathrm{pH}$ (6.3-7.03). In most nutrient content (N, P, K, $\mathrm{Mg}, \mathrm{Fe}, \mathrm{C}$, and IAA) tested for Panchakavya exceled over other four biofertilizers. Kunapanjola was found to have slightly higher $\mathrm{Ca}(0.20 \%), \mathrm{C}(3.02 \%)$, and GA (5.1 ppm) content over Panchakavya and other biofertilizers. Ali et al., (2011) have reported similar biochemical profile of organic biofertilizers such as Panachavya and Sanjibani. They have further indicated that these biofertilizers have near neutral $\mathrm{pH}$ and $\mathrm{EC}$ which supports the data obtained in this study.

Among the five indigenously prepared organic bioferilizers, Panchakavya was found to have higher density of fungi, actinomycetes and bacteria compared to other four fertilizers tested (Figure 1). On the other hand, higher phosphate solubilizer population was seen in Amritpani and free living N2 fixers in Kunapanjola (Figure 1). Sarkar et al., (2014) have reported the microbial richness in organic biofertilizers such as Panchakavya and Kunapanjola. Similar reports can be seen in the study that compares Panchakavya and Kunapanjola 
(Ali et al., 2011; Sreenivasa et al., 2011). It was recommended that the microbial richness may contribute to the plant growth and yield both directly and indirectly. Directly by increasing the rhizosphere microbial population and indirectly by increasing process of converting recalcitrant organic and inorganic compounds and releasing them for plant $\&$ microbial use.

Table.1 Physio-Chemical Characteristics of Five Biofertilizers Evaluated in this Study

\begin{tabular}{lccccc}
\hline Parameters & \multicolumn{5}{c}{ Biofertilizers tested } \\
\cline { 2 - 6 } & Panchagavya & Sanjibani & Amritpani & Jeevamrutha & Kunapajola \\
\hline pH & 6.3 & 6.7 & 6.8 & 7.03 & 9.1 \\
EC(dsm $\left.{ }^{-1}\right)$ & 8.5 & 9.6 & 7.5 & 7.9 & 10.2 \\
Total N (ppm) & 423.32 & 401.86 & 445.35 & 320.45 & 246.55 \\
Total P (ppm) & 198.58 & 173.65 & 187.56 & 177.11 & 131.11 \\
Total K (ppm) & 309.89 & 255.49 & 223.23 & 132.44 & 168.33 \\
Total Ca (\%) & 0.14 & 0.11 & 0.18 & 0.09 & 0.20 \\
Total Mg (\%) & 0.34 & 0.43 & 0.41 & 0.21 & 0.46 \\
Total Fe (ppm) & 120.68 & 110.7 & 100.33 & 98.33 & 102.12 \\
Total Zn (ppm) & 34.64 & 28.99 & 35.17 & 13.92 & 20.14 \\
Total organic & & & & & \\
carbon (\%) & 2.57 & 2.38 & 2.34 & 1.38 & 3.02 \\
IAA (ppm) & 7.1 & 6.2 & 7.5 & 6.4 & 5.8 \\
GA $(\mathrm{ppm})$ & 4.6 & 3.8 & 3.8 & 3.2 & 5.1 \\
\hline
\end{tabular}

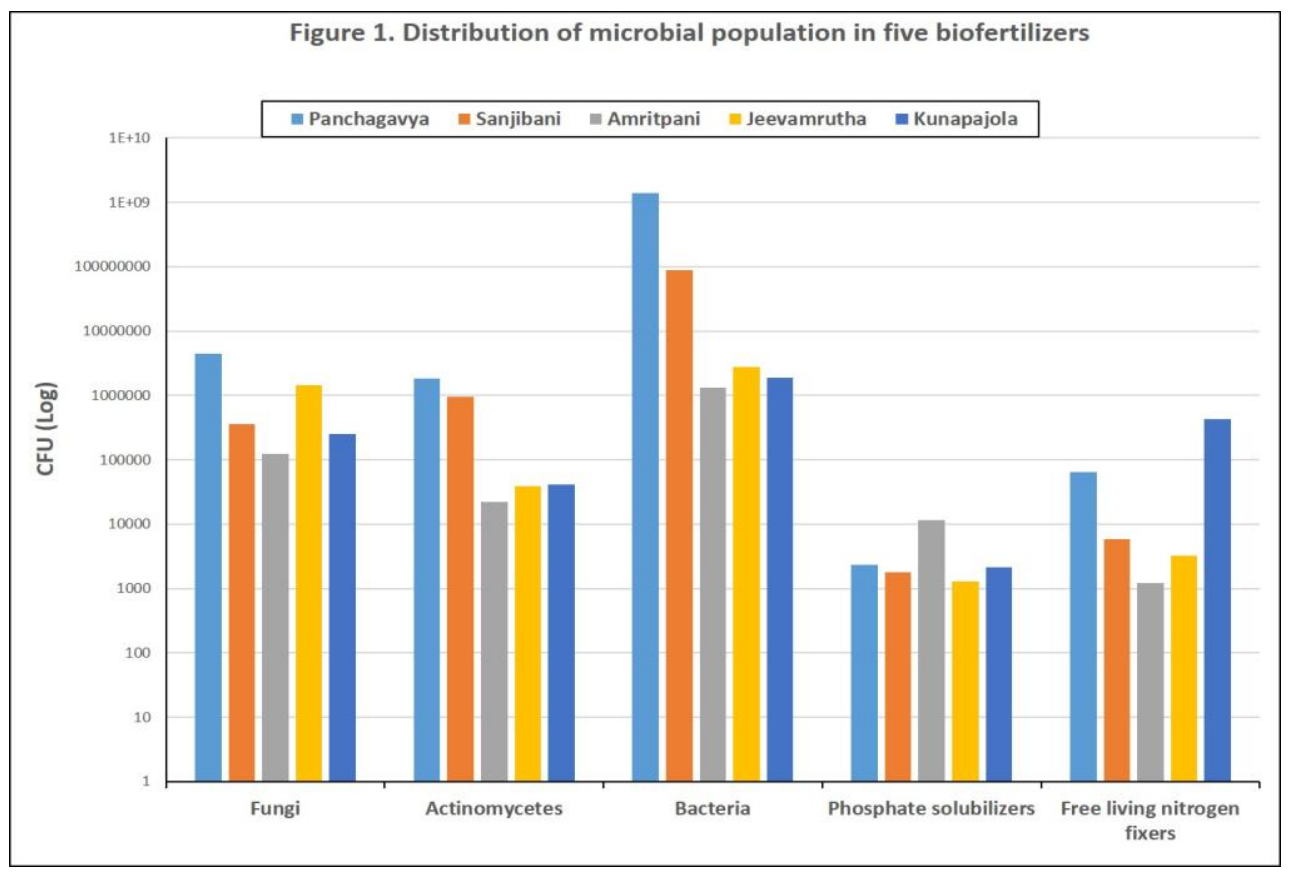



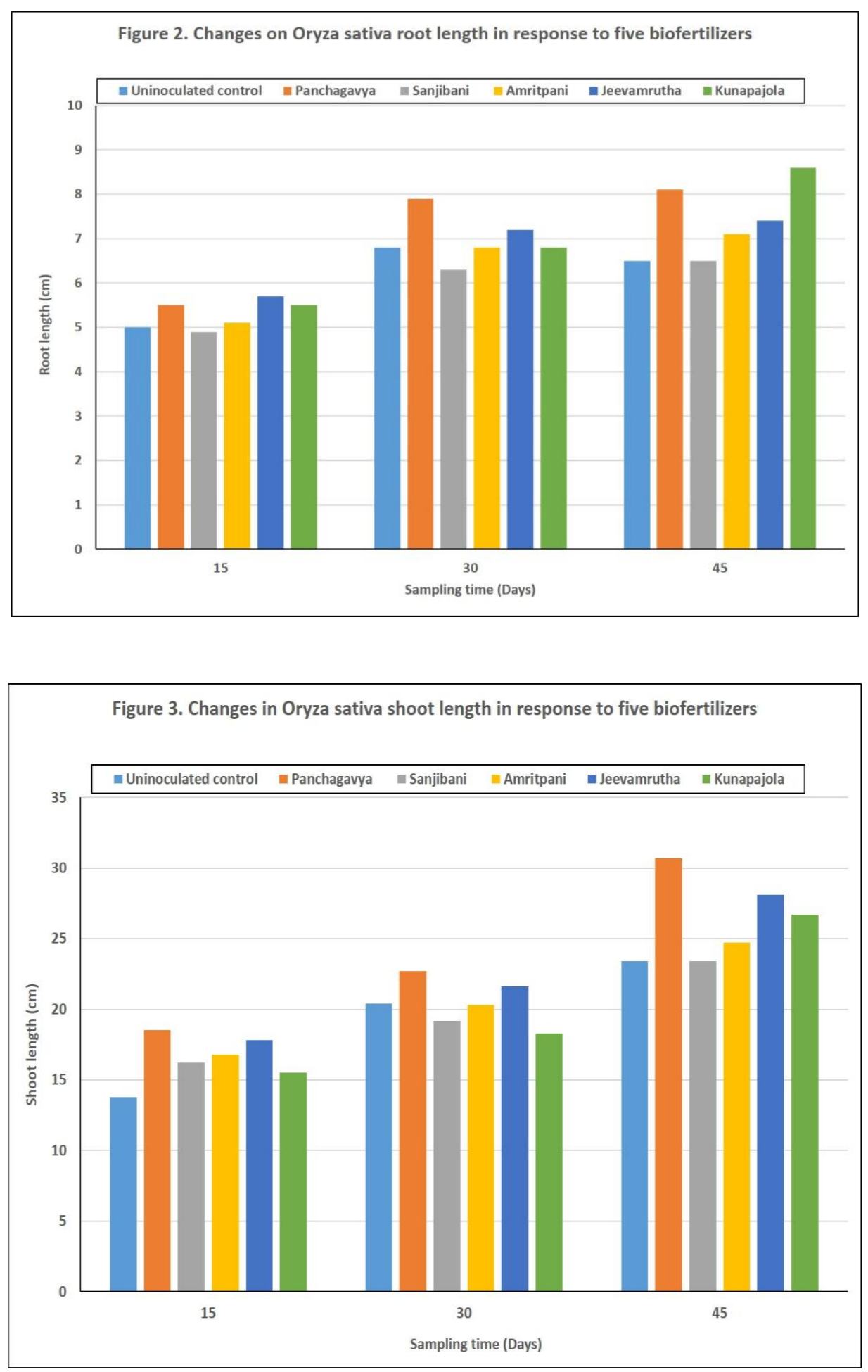

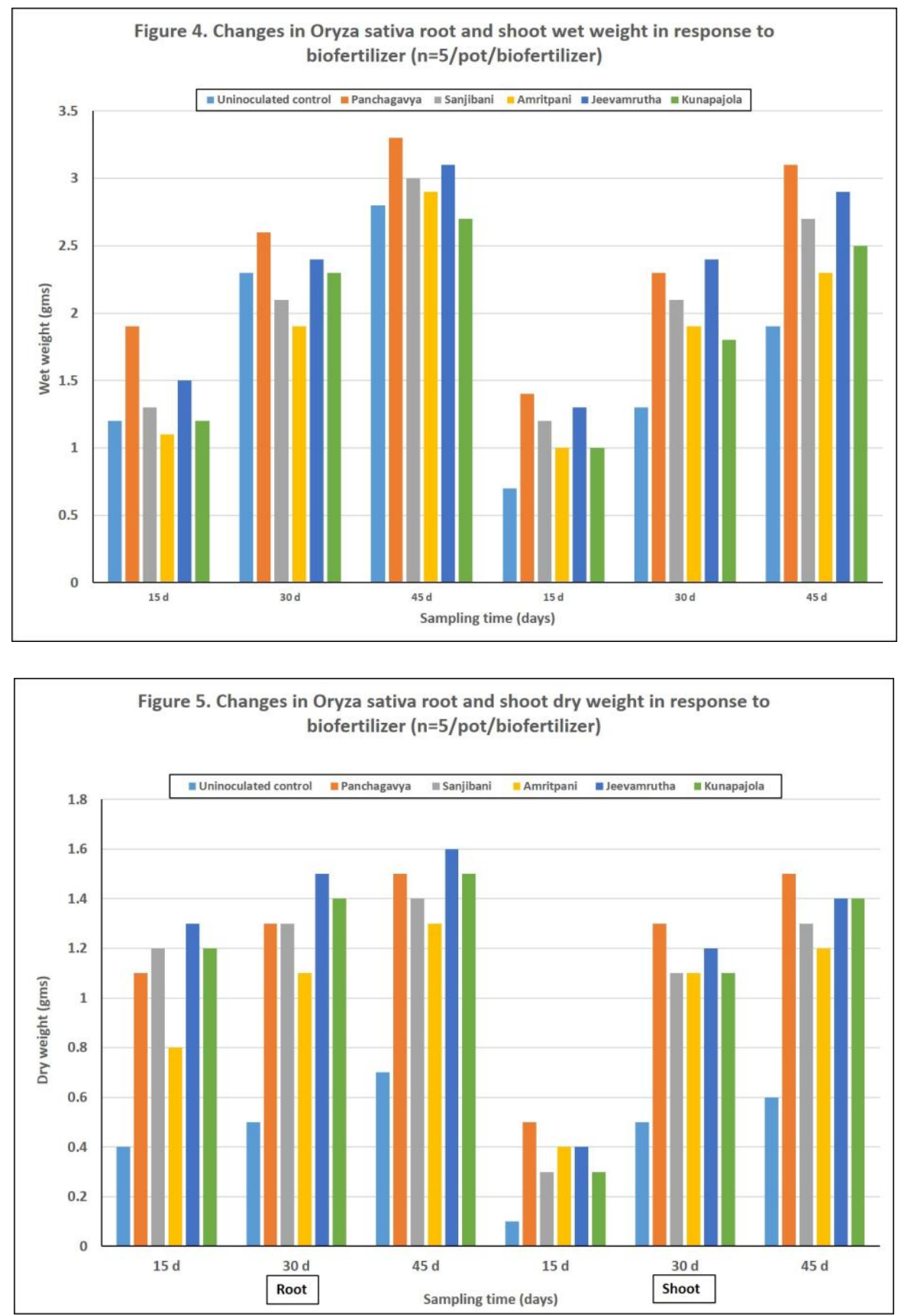

Oryza sativa was tested for its response to nutrient supplement in the form of the five organic biofertilizers. Figure 2 presents the data pertaining to the changes in root length of the test plant in response to the biofertilizers. While Panchakavya seems to encouraged the plant growth in terms of root length till 30 days post application, seeds supplemented with Kunapanjola seems to have slightly better germination rate as seen with the longer roots over other biofertilizers amended pots (Figure 2). On other hand, Panchakavya amended pots exhibited better shoot length of seeded paddy plant compared to other amendments in all 3 sampling time point (Figure 3). This was 
statistically significant $\quad(p<0.05)$ when compared to the uninoculated control plants. This pattern was consistent in the root and shoot wet weight (Figure 4) with Panchakavya being the best. Even though there was a slightly increase in the root dry weight in pots supplemented with Jeevamurtha, Panchakavya was seen to have a positive impact on the shoot dry weight (Figure 5). These observations were amply supported by several investigators with different plants and organic biofertilizers. Rajesh et al., (2013) have reported the positive impact of Panchagavya on Abelmoschus esculents (L.) Moench when applied as foliar spray. This application has yielded a modest increase in black gram plant yield and was attributed to the biochemical and microbial population in Panchakavya (Rajesh et al., 2013). Similar growth promoting and yield enhancing effects in organic biofertilizers were reported by several other researchers (Sarkar et al., 2014; Chudhary et al., 2014; Ali et al., 2011; Sreenivasa et al., 2013).

In conclusion, this study categorically demonstrates the efficacy and relevance of organic biofertilizers for plant growth and yield. Among the biofertilizers tested, Panchakavya followed by Kunapanjola the most promising biofertilizers warrants large scale field studies to ascertain their application potentials and cost economics for feasibility.

\section{References}

Ali MN., Ghatak S, and Ragul T. 2011.
Biochemical analysis of Panchagavya and Sanjibani and their effect in crop yield and soil health. J Crop Weed 7(2): 84-86

Sreenivasa MN, Naik N, and Bhat SN. 2011. Nutrient status and microbial load of different organic liquid manures. Karnataka J. Agric. Sci., 24 (4): 583584

Choudhary KM, Patel MM, and Pagar RD. 2014. Effect of foliar application of Panchagavya and leaf extracts. of endemic plants on groundnut (Arachis hypogel L) Legume Res., 37 (2) : 223 $-226$

Sarkar S, Kundu SS and Ghorai D. 2014. Validation of ancient liquid organics Panchagavya and Kunapanjala as plant growth promoters. Indian $J$ Traditional Knowledge (13)2: 398-403

Rajesh M and Jayakumar K. 2013. Changes in morphological, biochemical and yield parameters of Abelmoschus esculents (L.) Moench due to Panchagavya Spray. Int. J Modern Plant \& Animal Sciences 1(2): 82-95

Natarajan K. 2002. Panchagavya - A manual. Other India Press, Mapusa, Goa, India, pp. 33.

Geetha S and Devaraj A. 2013. Effect of microbial fertigation and Panchagavya on the growth of Vitis vinifera graftings. Int. J Biosci Res., (2)4: 1-6

Cappuccino JG. 2014. Microbiology: A laboratory manual, $13^{\text {th }} \mathrm{Ed}$.

Natarajan K, 2007, 'Panchagavya for plant', Proc. Nation. Conf. Glory Gomatha, 72-75.

\section{How to cite this article:}

Ramya Anandan, Lakshmi Priya and Rajendran, P. 2016. Dynamics of Organic Biofertilizers on Oryza sativa ADT43. Int.J.Curr.Microbiol.App.Sci. 5(3): 902-908.

doi: http://dx.doi.org/10.20546/ijcmas.2016.503.104 